\title{
Comparative Studies on the UV Radiations Resistance of Some Painting Materials
}

\author{
TRAIAN RUS ${ }^{1}$, IOSIF LINGVAY², ALINA RUXANA CARAMITU2, ADRIANA MARIANA BORS³, DANUT IONEL VAIREANU1* \\ ${ }^{1}$ Politehnica University of Bucharest, Faculty of Applied Chemistry and Materials Science, Department of Analytical Chemistry \\ and Environmental Engineering, 1-7 Polizu Str., 011061, Bucharest, Romania \\ 2.National Institute for Research and Development in Electrical Engineering INCDIE ICPE-CA, 313, Splaiul Unirii, 030138, \\ Bucharest, Romania, \\ 3The National Institute for Research and Development in Environmental Protection (INCDPM), 294 Splaiul Independentei, \\ 060031, Bucharest, Romania
}

\begin{abstract}
UV radiation has a long-term effect on the durability of anti-corrosive coatings applied by painting, generating conditions for accelerated localized corrosion of the protected metallic structure with adverse effects on operational safety. This paper presents a comparative study of the behavior of some painting materials ageing by exposure to UV radiation relevant by the investigation of dielectric behavior using dielectric spectroscopy in conjunction with the thermal stability investigated by coupled techniques of thermal analysis. From a practical point of view, the UV radiation behavior of two materials based on epoxy resins and polyurethane resin used as paints for protective decorative coatings was studied. The results of experimental investigations have shown that in the aging process of the studied painting materials there is a direct correlation between the evolution of the maximum temperature characteristic of the first thermooxidation process and the evolution of the dielectric performances (dielectric loss - tg $\delta$ ).
\end{abstract}

Key words: paints degradation, UV resistance, dielectric spectroscopy, thermal stability, epoxy paints, polyurethane paints

With a view to sustainable development, the sustainability and safety in exploitation of metal structures in a wide variety of fields such as energy infrastructure, marine drilling platforms, art works related to transport infrastructure (bridges and viaducts), etc., is an interdisciplinary issue of great practical importance with remarkable economic, social and ecological implications.

The durability and safety in exploitation of metallic structures is primarily determined by their corrosion degradation due to the concerted and synergistic actions of stress factors specific to the operating environment acting on both the support metal and the coatings applied bypainting.

Degradation of the paint film creates conditions for the localized corrosion of the metal structure primarily in the joining areas [1]. Thus, the resistance structure of the metal structure is affected, being frequently compromised (demolished) [1] under the action of increased demands (wind, hoar-frost etc.).

Paints used to protect industrial constructions are made on based of organic resins (usually epoxy polymers, urethane, etc.).

Under the action of environmental factors [2] (temperature variations $[3,4]$, atmospheric oxygen, solar radiation (especially IR and UV [5 to 9]), polymers suffer a series of consecutive process and/or parallel (polymerization, crosslinking, thermooxidation, degradation by the breakage of $\mathrm{C}-\mathrm{C}$ bonds, etc.).

Therefore, the film material undergoes a series of structural changes [10], contracts [11] and cracks [12], changes its mechanical characteristics [13] and loses its protective qualities (increases both the permeability for oxygen diffusion and atmospheric $\mathrm{CO}_{2}$ to metal as well as electrical conductivity $[14,15]$, which activates the local corrosion cells). On the other hand, due to the breakdown of polymer chains and growth (by crosslinking) of tertiary

* email: di_vaireanu@chim.upb.ro; Phone: +4 0214023939 and quaternary carbon content, decreases the resistance of polymers from paint materials to moulds action $[3,17-$ 22]. Recent studies [23-25] have highlighted the fact that the electric field with $50 \mathrm{~Hz}$ industrial frequency stimulates enzymatic activity [26], the metabolism and the multiplication of moulds, which makes as in polluted electromagnetic environments [27-29] degradation of polymers [3, 19,30] and metal corrosion [31-39] are substantially accelerated. In this context, many studies address both the issue of the influence of UV radiation on the physico-chemical performances of the polymers used to make the painting materials [5-10, 40-43] and the development of high-resistance polymeric materials to microbiological factors [44-49 ] and / or with controlled biodegradability $[48,50]$.

Thanks to the facilities they offer, coupled techniques of thermal analysis (TG + DTG + DTA) are commonly used $[10,16,19,51-56]$ to study structural changes in polymeric materials as a result of exposure to stress factors action (thermal, UV, etc.).

The durability being the residual life of metallic structures protected by coatings paints can be assessed by intelligent preventive and predictive diagnostics studies [57]. Carrying out predictive diagnosis studies involves knowing the behavior of materials under the influence of stress factors acting upon them during exploitation $[57,58]$.

In view of these considerations, the aim of the paper is to study the dielectric behavior (by dielectric spectroscopy) and the thermal stability (by coupled techniques of thermal analysis) of the behavior of coating materials aged by exposure to UV radiation.

\section{Experimental part}

Materials and methods

The behavior under the action of UV radiations of the two materials, paints based on epoxy resins and polyurethane resins was studied (table 1 ). 


\begin{tabular}{|c|c|c|}
\hline Samples code & Brand name & Resin type \\
\hline \hline PMS-1 & Sigmacover 456 [59] & Epoxy \\
\hline PMS-2 & Intergard 410 [60] & Modified epoxy \\
\hline PMS-3 & Hardtop [61] & Acrylic polyurethane \\
\hline PMS-4 & Sigmadur 550H [62] & Polyurethane \\
\hline
\end{tabular}

Table 1

THE INVESTIGATED PAINT MATERIALS

Fig. 1. Thermograms obtained on the PMS1 epoxy paint sample- initially

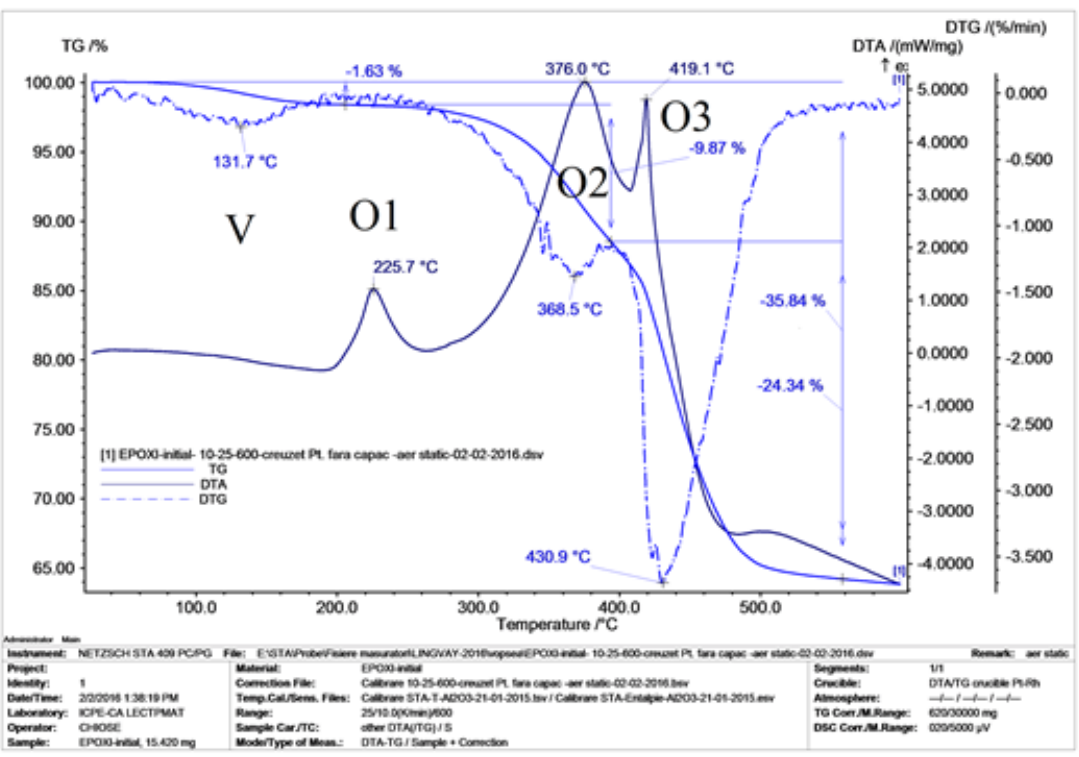

For obtaining the samples, the painting materials investigated were applied by brushing on a polyethylene film support. After curing ( 10 days at $25 \pm 30^{\circ} \mathrm{C}$ ), the paint materials were detached having a dry film thickness between 80 and $120 \mu \mathrm{m}$.

The paint films thus obtained were exposed to UV radiations in controlled conditions ( $\lambda=300-400 \mathrm{~nm}, 60 \mathrm{~W} /$ $\mathrm{m}^{2}$ at $50 \pm 2^{\circ} \mathrm{C}$ and relative humidity $\mathrm{RH} 50 \pm 5 \%$ equipment: XENOTEST 440, ATLAS - Material Testing Solutions)

The dielectric behavior of paint films - both the initial and to various UV exposure times - was investigated at 20 $\pm 2{ }^{\circ} \mathrm{C}$ by dielectric spectroscopy technique with 1296 Dielectric interface / AMTEK - Solartron Analytical.

From the original paint samples and the aged samples by UV exposure, 15-50 mg samples were taken, which were investigated by coupled techniques of thermal analysis (TG + DTA + DTG) with STA 409 PC specialized equipment produced by Netsch (Germany).

The determinations were made in static air with heating from ambient temperature up to $600^{\circ} \mathrm{C}$ at a speed of $10 \mathrm{~K} /$ $\min$.

\section{Results and discussion}

The characteristic TG, DTG and DTA thermograms obtained by the progressive heating of the original PMS1 paintsample based on epoxy resin (before exposure to UV radiation) are shown in figure 1 . Thermograms shape obtained on the PSM2 initial sample (also based on epoxy resin) are similar to those in figure 1 - the differences being observed only at the characteristic temperatures of the different processes.

From the analysis of figure 1 . it is noted that the progressive heating in static air of PSM1 material between ambient temperature and approx. $200^{\circ} \mathrm{C}$ there is an endothermic $\boldsymbol{V}$ process of decomposition with the formation of volatile products, the loss of recorded mass being of $\Delta \boldsymbol{m}_{v}=1.63 \%$. At approx. $200^{\circ} \mathrm{C}$ triggers an exothermic 01 oxidation process with the formation of solid peroxide products (without mass loss), a process having the maximum speed at $T_{\text {Maxol }}=225.7^{\circ} \mathrm{C}$.

At temperatures higher than $300^{\circ} \mathrm{C}$ two exothermic processes of oxidation occur with the formation of volatile products 02 and $\mathbf{0 3}$ with the characteristic temperatures $T_{\text {Max02 }}=376.0 \mathrm{vC}$ and $T_{\text {Max03 }}=419.1^{\circ} \mathrm{C}$ with mass losses $\Delta \boldsymbol{m}_{02}^{\mathrm{Max02}}=9.87 \%$ and $\Delta \boldsymbol{m}_{03}^{\text {Max03 }_{2}} 24.34 \%$; total mass losses up to $600^{\circ} \mathrm{C}$ being $35.84 \%$.

As a result of exposure to UV radiation, the thermal behavior of the epoxy material PMSI changes substantially - as illustrated in the thermograms in figure 2.

By analyzing figure 2, it is observed that at the progressive heating of the ageing PMS1 material by UV irradiation for $92 \mathrm{~h}$, up to approx. $190^{\circ} \mathrm{C}$ an endothermic process $\boldsymbol{V}$ of decomposition takes place, the loss of recorded mass being of $\Delta \boldsymbol{m}_{v}=2.34 \%$, followed by a strong endothermic melting process (no mass loss) with characteristic temperature $T_{M}=216.3^{\circ} \mathrm{C}$.

Compared to figure 1 it is noted that the weight of the exothermic process of thermooxidation without loss of 01 mass (with the formation of peroxide products) is much attenuated and takes place at significantly higher temperature, respectively at $T_{\text {Max } 1}=281.5^{\circ} \mathrm{C}$, suggesting that after UV irradiation decreases the weight of quaternary and tertiary carbon atoms (with higher activity in the formation of solid peroxide products) in the polymer structure.

Exothermic processes of thermooxidation with the formation of volatile products $\mathbf{0 2}$ and $\mathbf{0 3}$ occur at lower temperatures than before UV irradiation, respectively at $T_{\text {Max02 }}=371.8^{\circ} \mathrm{C}$ and $T_{\text {Max } 03}=396.7^{\circ} \mathrm{C}$ with mass losses $\Delta \stackrel{M}{m}_{02}=7.75 \%$ respectively $\Delta \boldsymbol{m}_{03}=29.13 \%$, the total mass losses up to $600^{\circ} \mathrm{C}$ being $\Delta \boldsymbol{m}_{1}=39.2 \%$. Thermograms shape recorded on the PMS1 and PMS2 samples at different irradiation times were similar to those 

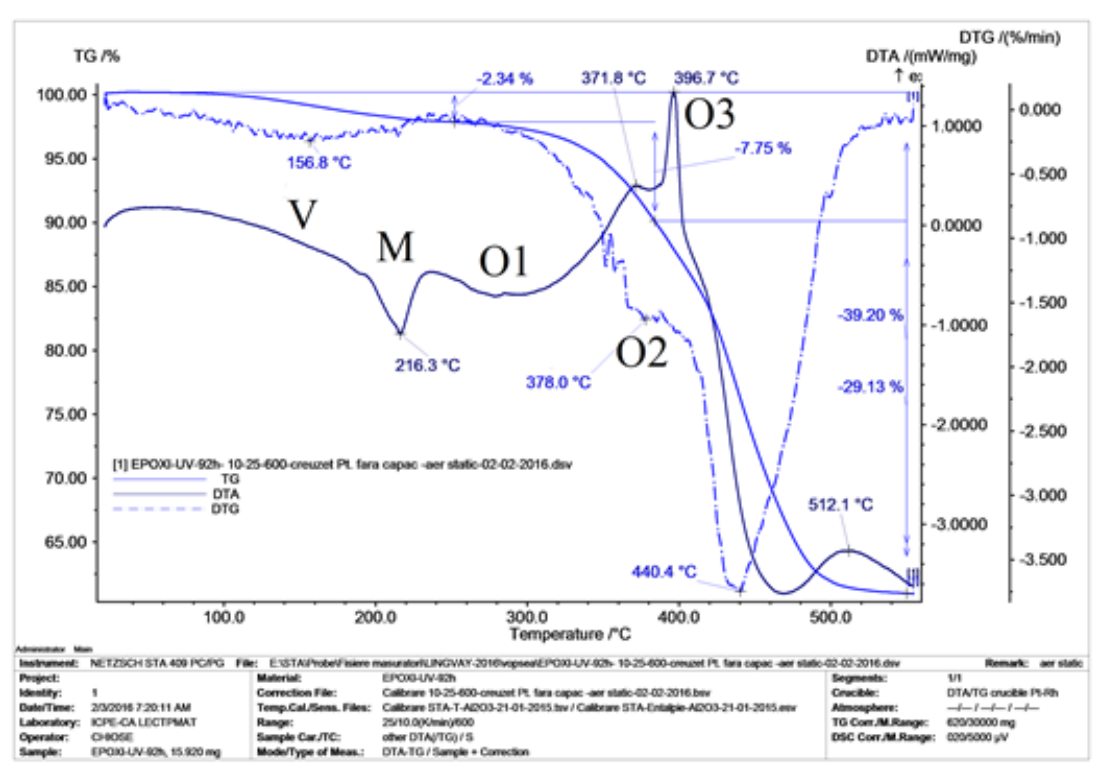

Fig. 2. Thermograms obtained on the PMS1 epoxy paint sample after $92 \mathrm{~h}$ exposure to UV $60 \mathrm{~W} / \mathrm{m}^{2}$

Table 2

CHARACTERISTIC THERMAL PARAMETERS RECORDED ON THE SAMPLES OF EPOXY MATERIALS INVESTIGATED

\begin{tabular}{|c|c|c|c|c|c|c|c|c|c|c|c|c|c|c|c|c|}
\hline \multirow{4}{*}{ 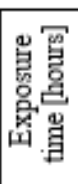 } & \multicolumn{8}{|c|}{ Material: PMSI } & \multicolumn{8}{|c|}{ Material: $P M S 2$} \\
\hline & \multicolumn{7}{|c|}{ Process: } & \multirow{3}{*}{$\begin{array}{c}\Delta m_{\mathrm{T}} \\
\& \\
600^{\circ} \mathrm{C} \\
{[\%]}\end{array}$} & \multicolumn{7}{|c|}{ Process: } & \multirow{3}{*}{$\begin{array}{c}\Delta m_{\mathrm{I}} \\
\& \\
600^{\circ} \mathrm{C} \\
{[\%]}\end{array}$} \\
\hline & V & $\mathrm{M}$ & 01 & \multicolumn{2}{|c|}{02} & \multicolumn{2}{|c|}{03} & & \multirow{2}{*}{\begin{tabular}{|c|}
$\mathrm{V}$ \\
$\Delta \mathrm{mV}$ \\
{$[\%]$} \\
\end{tabular}} & \multirow{2}{*}{$\begin{array}{c}\mathrm{M} \\
T_{M} \\
{\left[{ }^{\circ} \mathrm{C}\right]}\end{array}$} & \multirow{2}{*}{\begin{tabular}{|c|}
01 \\
$T_{\text {MexOI }}$ \\
{$\left[{ }^{\circ} \mathrm{C}\right]$} \\
\end{tabular}} & \multicolumn{2}{|c|}{02} & \multicolumn{2}{|c|}{03} & \\
\hline & $\begin{array}{c}\Delta \mathrm{mv} \\
{[\%]}\end{array}$ & $\begin{array}{c}T_{M} \\
{\left[{ }^{\circ} \mathrm{C}\right]}\end{array}$ & $\begin{array}{c}T_{\text {MaxOI }} \\
{\left[{ }^{\circ} \mathrm{C}\right]}\end{array}$ & $\begin{array}{c}T_{\text {MaxOn }} \\
{\left[{ }^{\circ} \mathrm{C}\right]}\end{array}$ & \begin{tabular}{|c}
$\Delta m_{O 2}$ \\
{$[\%]$}
\end{tabular} & {$\left[{ }^{\circ} \mathrm{C}\right.$} & $\begin{array}{c}\Delta m_{O 2} \\
{[\%]}\end{array}$ & & & & & $\begin{array}{c}T_{\text {MaxOI }} \\
{\left[{ }^{\circ} \mathrm{C}\right]}\end{array}$ & \begin{tabular}{|c}
$\Delta m_{O z}$ \\
{$[\%]$}
\end{tabular} & & & \\
\hline 0 & 1.63 & the & 225,7 & 376.0 & 9.87 & 419.1 & 24.34 & 35.84 & 1.95 & $x-1$ & 229.8 & \begin{tabular}{|l|}
371.1 \\
\end{tabular} & 10.11 & 413.2 & 26.55 & 38.62 \\
\hline 20 & 1.68 & 200.6 & 278.1 & 378.3 & 11.05 & 420.1 & 23.76 & 36.36 & 2.21 & 201.1 & 235.1 & 372.3 & 12.51 & 415.5 & 24. & 38.95 \\
\hline 68 & 1.71 & 205.7 & 271.1 & 364.2 & 7.58 & 408.6 & 27.71 & 37. & 2.53 & 205.5 & 280.1 & 362 & 8.34 & 41 & & 40.1 \\
\hline 92 & 2.34 & 216.3 & 281.5 & 371.8 & 7.75 & 396.7 & 29.13 & 39.20 & 2.86 & 209.2 & 288.5 & 365.5 & 8.96 & 391.1 & 31.45 & 43.2 \\
\hline 150 & 2.69 & 229.2 & 5.1 & 360.1 & 7.45 & 390.9 & 30.11 & 40.25 & 3.11 & 215.2 & 279.1 & 351.2 & 8.43 & 380.2 & 32 & 43.8 \\
\hline 200 & 85 & 37.1 & 65.1 & 356.9 & 7.12 & 387.1 & 31.13 & 41.11 & 3.81 & 230.1 & 270.1 & 347.1 & 8.01 & 371.3 & 35.81 & 47.6 \\
\hline
\end{tabular}

in figure 2- the recorded differences being in the characteristic parameters $\boldsymbol{T}$ and $\Delta \boldsymbol{m}$.

In table 2 the characteristic parameters of the thermal behavior of PMS1 and PMS2 initial and irradiated with UV (60 W/m $/ \mathrm{m}^{2}$ at various times) are synthetically and comparatively presented.

By analyzing the data in table 2 , it is noted that for the epoxy materials PMS1 and $\mathbf{P M S 2}$ investigated at increased UV exposure time $\left(60 \mathrm{~W} / \mathrm{m}^{2}\right)$ the mass losses $\Delta \boldsymbol{m}_{v}$ due to the formation of volatile products increase, higher increases being recorded at PMS2. It is noted that in the first $20 \mathrm{~h}$ of UV exposure of PMS1 and PMS2 samples a structural ordering process appears that significantly increases the crystallinity of the material, indicating an endothermic $T_{M}$ peak corresponding to the melting process. Both for PMS1 and PMS2, when increasing UV exposure times, $\boldsymbol{T}_{M}$ increases monotonous, indicating a continuous increase in molecular weight of the polymer by the chain elongation and/or crosslinking.

The results of the dielectric spectroscopy and the dielectric loss $(\operatorname{tg} \delta$ ) depending on the duration of exposure to UV $60 \mathrm{~W} / \mathrm{m}^{2}$ are presented for PMS1 in figure 3 and in figure 4 for PSM2.

By analyzing figure 3 and figure 4 it is noted that both PSM1 and PSM2, in the first approx. $90 \mathrm{~h}$ of UV irradiation, respectively up to an irradiation dose of approx. 19.5 MJ/ $\mathrm{m}^{2}$, dielectric losses in investigated materials decrease continuously. When increasing the radiation dose above $19.5 \mathrm{MJ} / \mathrm{m}^{2}$, the dielectric losses increase.

It is also noted that systematic dielectric losses in PSM1 are lower than in PSM2, and that tgs increases at the dose of $19.5 \mathrm{MJ} / \mathrm{m}^{2}$ are more pronounced in PSM2 than in PSM1.

These developments of $\operatorname{tg} \delta$ suggest that at the beginning of exposure to UV (up to $19.5 \mathrm{MJ} / \mathrm{m}^{2}$ ) the polymer structure

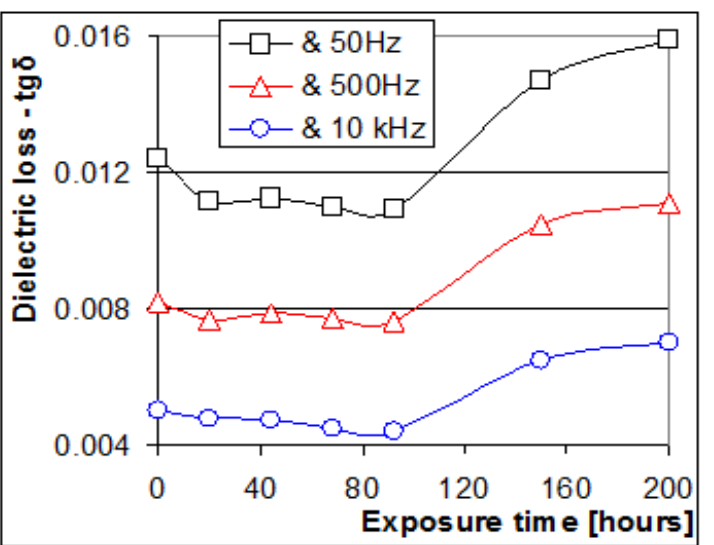

Fig. 3. The evolution of dielectric losses at PSM1 depending on the duration of exposure to UV $60 \mathrm{~W} / \mathrm{m}^{2}$

stabilizes, after which, at exposures longer than approx. $90 \mathrm{~h}\left(\right.$ at $\left.60 \mathrm{~W} / \mathrm{m}^{2}\right)$ structural degradation of the polymer takes place.

By comparing figure 3 and figure 4 with the data from table 2 it is observed that the minimum values of tg $\delta$ correspond to the maximum values of $T_{\text {Maxol }}$ respectively the maximum thermal stability of the material.

The thermograms recorded on the initial PSM4 polyurethane resin based paint material and after exposure to UV $60 \mathrm{~W} / \mathrm{m}^{2}$ are shown in figure 5 respectively figure 6 .

The analysis of figure 5 show that a progressive heating of the PSM4 polyurethane material can identify a first endothermic $M$ process at $T_{M}=270^{\circ} \mathrm{C}$ (probably the melting of the material) with which simultaneously begins a first exothermic oxidation process 01 - with $T_{\text {Max } 01}=$ $392.5^{\circ} \mathrm{C}$, accompanied by the formation of volatile products and a significant mass loss of $\Delta \boldsymbol{m}_{01}=20.16 \%$. 


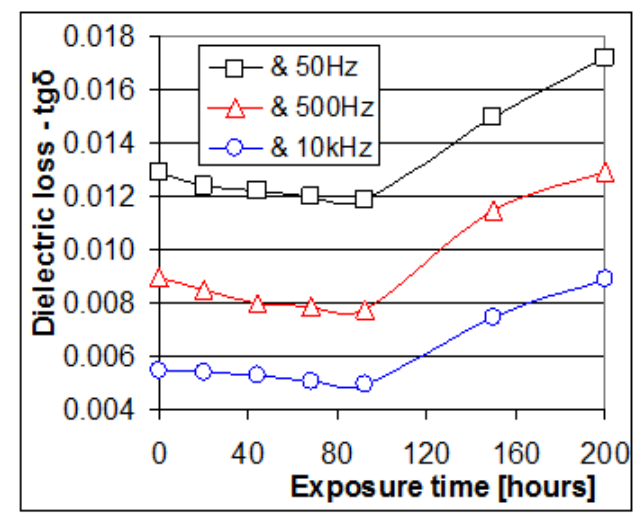

Fig. 4. The evolution of dielectric losses at PSM2 depending on the duration of exposure to UV $60 \mathrm{~W} / \mathrm{m}^{2}$
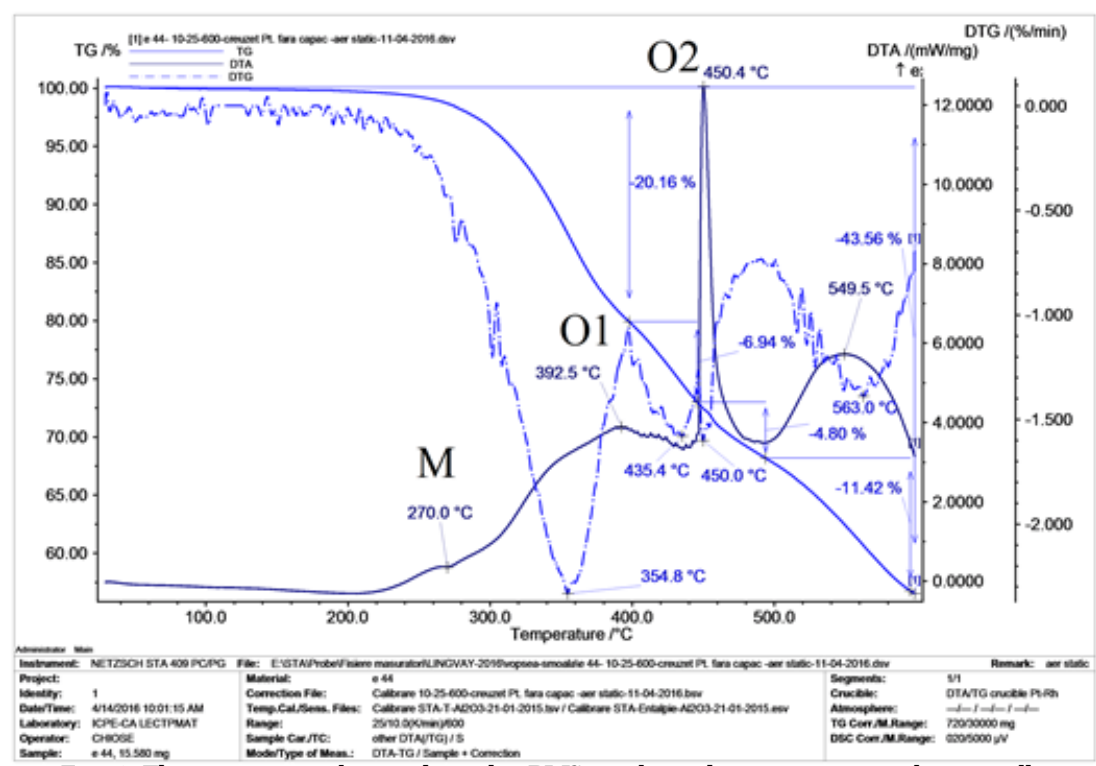

Fig. 5. Thermograms obtained on the PMS4 polyurethane paint sample- initially
These are followed by several exothermic oxidation processes (with mass loss), of which $\mathbf{0 2}$ is most important with $T_{M a 02}=450.4^{\circ} \mathrm{C}$ and $\Delta \boldsymbol{m}_{03}=6.94 \%$ - the total mass loss up to $600^{\circ} \mathrm{C}$ is $\Delta \boldsymbol{m}_{\boldsymbol{T}}=45.93 \%$.

By comparing fgiure 5 with figure 6 it is observed that after the UV exposure of the PSM4 material, its structure changes, causing an endothermic $\boldsymbol{V}$ process with formation of volatile products before the melting of the material, after which up to approx. $220^{\circ} \mathrm{C}$ the mass loss is $\Delta \boldsymbol{m}_{v}=3.21 \%$. It is also noted that the process $\boldsymbol{M}$ is more pronounced and takes place at a temperature of $\boldsymbol{T}_{M}=276.4$ ${ }^{\circ} \mathrm{C}$ (higher than for the initial material with $6.4^{\circ} \mathrm{C}$ ) and that the characteristic temperature of the firstoxidation process 01 is $T_{\text {Maxo1 }}=341.0^{\circ} \mathrm{C}$ (with $51.5^{\circ} \mathrm{C}$ lower than for the original, non-irradiated material).

$T_{\text {g }}$ grow th indicates that an increase in molecular weight and structural ordering level occurs during UV exposure, and the decrease in $T_{\text {Maxo }}$ indicates that these changes are due to an increase in the cross-linking degree of the polymer.

The thermograms shappe recorded on the $\mathbf{P M S 3}$ and PMS4 samples at various irradiation times (UV $60 \mathrm{~W} / \mathrm{m}^{2}$ ) were similar to those in figure 5 respectively figure 6 - the differences recorded being in the characteristic parameters $\boldsymbol{T}$ and $\Delta \boldsymbol{m}$.

In table 3 the characteristic parameters of the thermal behavior of $\boldsymbol{P M S 3}$ and $\boldsymbol{P M S 4}$ initial and irradiated with UV
(60 W/m $/ \mathrm{m}^{2}$ at various times) are synthetically and comparatively presented.

The data from table 3 show that for both investigated polyurethane materials, the $T_{\text {Maxo1 }}$ temperature in the first $92 \mathrm{~h}$ of exposure to UV increases, indicating an increase in thermal stability of the material. At times of exposure to UV longer than $92 \mathrm{~h}, T_{\text {Maxo1 }}$ decreases and $T_{M}$ significantly increases indicating excessive crosslinking of the material resulting in lower global thermal stability ( $T_{\text {MaxO1 }}$ and $T_{\text {MaxO2 }}$ decreases and increases $\Delta \boldsymbol{m}_{T} \& 600^{\circ} \mathrm{C}$ ).

The results of the determined dielectric spectroscopy and dielectric losses evolution ( $\operatorname{tg} \boldsymbol{\delta})$ depending on the duration of exposure to UV, $60 \mathrm{~W} / \mathrm{m}^{2}$ are presented for PMS3 in figure 7 and in figure 8 for PSM4.

By the analysis of figure 7 and figure 8 it is found that both PSM3 and PSM 4, in the first approx. $70 \mathrm{~h}$ of UV irradiation, respectively up to an irradiation dose of approx. $15.1 \mathrm{MJ} / \mathrm{m}^{2}$, the dielectric losses in the investigated materials decrease continuously. When increasing the radiation dose over $15.1 \mathrm{MJ} / \mathrm{m}^{2}$, the increase in dielectric losses is assured, the increases being more pronounced at PSM3.

These developments of tg $\delta$ suggest that at the beginning of UV exposure (up to $15.1 \mathrm{MJ} / \mathrm{m}^{2}$ ) the polymer structure stabilizes, after which, at exposures longer than approx. $70 \mathrm{~h}\left(\right.$ at $\left.60 \mathrm{~W} / \mathrm{m}^{2}\right)$ structural degradation of the polymer occurs.

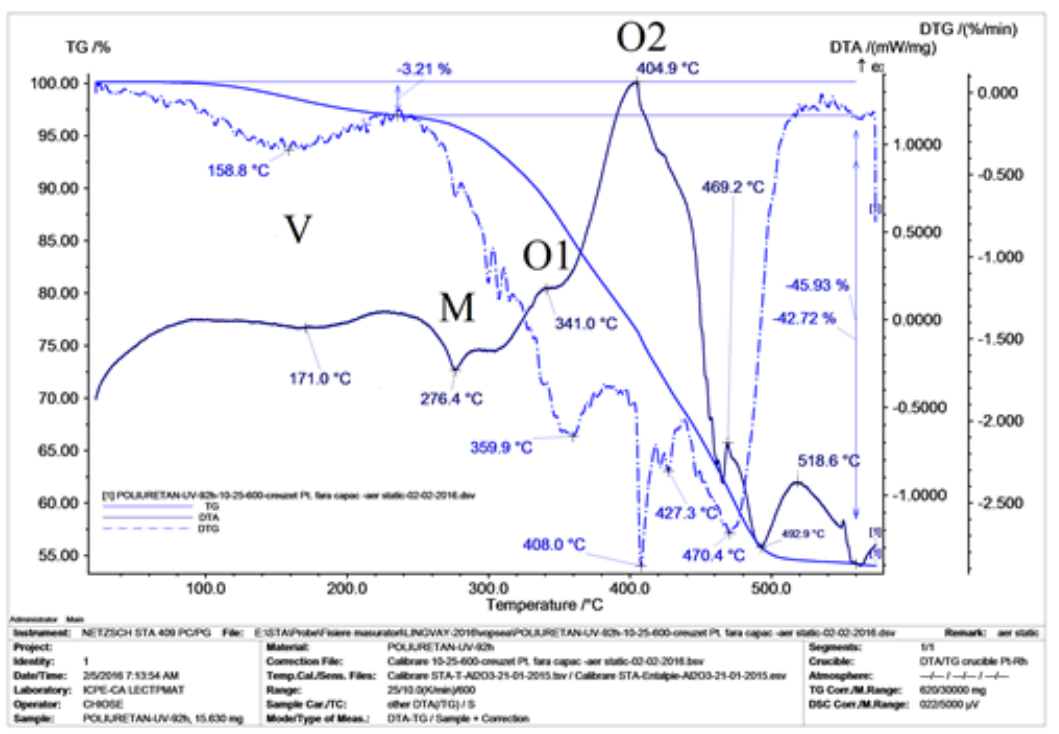

Fig. 6. Thermograms obtained on the PMS4 polyurethane paint sample after $92 \mathrm{~h}$ exposure to UV $60 \mathrm{~W} / \mathrm{m}^{2}$ 
Table 3

CHARACTERISTIC THERMAL PARAMETERS RECORDED ON THE SAMPLES OF INVESTIGATED POLYURETHANE MATERIALS

\begin{tabular}{|c|c|c|c|c|c|c|c|c|c|c|c|c|c|c|}
\hline \multirow{4}{*}{ 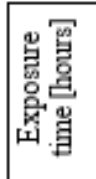 } & \multicolumn{7}{|c|}{ Material: PMS3 } & \multicolumn{7}{|c|}{ Material: PMS4 } \\
\hline & \multicolumn{6}{|c|}{ Process: } & \multirow{3}{*}{$\begin{array}{c}\Delta m_{T} \\
\& \\
600^{\circ} \mathrm{C} \\
{[\%]}\end{array}$} & \multicolumn{6}{|c|}{ Process: } & \multirow{3}{*}{$\begin{array}{c}\Delta m_{T} \\
\& \\
600^{\circ} \mathrm{C} \\
{[\%]}\end{array}$} \\
\hline & $\nabla$ & $\mathrm{M}$ & \multicolumn{2}{|c|}{01} & \multicolumn{2}{|c|}{02} & & $\mathrm{~V}$ & $\mathrm{M}$ & \multicolumn{2}{|c|}{01} & \multicolumn{2}{|c|}{02} & \\
\hline & $\begin{array}{l}\Delta \mathrm{mv} \\
{[\%]}\end{array}$ & $\begin{array}{c}T_{M} \\
{\left[{ }^{\circ} \mathrm{C}\right]}\end{array}$ & $\begin{array}{c}T_{\mathrm{MaxO}} \\
{\left[{ }^{\circ} \mathrm{C}\right]}\end{array}$ & $\begin{array}{c}\Delta m_{O I} \\
{[\%]}\end{array}$ & $\begin{array}{c}T_{\mathrm{MaxOZ}} \\
{\left[{ }^{\circ} \mathrm{C}\right]}\end{array}$ & $\begin{array}{c}\Delta m_{O 2} \\
{[\%]}\end{array}$ & & $\begin{array}{c}\Delta \mathrm{mv}_{\mathrm{V}} \\
{[\%]}\end{array}$ & $\begin{array}{c}T_{M} \\
{\left[{ }^{\circ} \mathrm{C}\right]}\end{array}$ & $\begin{array}{c}T_{\mathrm{MaxOI}} \\
{\left[{ }^{\circ} \mathrm{C}\right]}\end{array}$ & $\begin{array}{c}\Delta m_{O I} \\
{[\%]}\end{array}$ & $\begin{array}{c}T_{\mathrm{Max} O \mathrm{OZ}} \\
{\left[{ }^{\circ} \mathrm{C}\right]}\end{array}$ & $\begin{array}{c}\Delta m_{O 2} \\
{[\%]}\end{array}$ & \\
\hline 0 & - & 265,9 & 391.3 & 22.11 & 423.2 & 21.31 & 49.34 & - & 270.0 & 392.5 & 20.16 & 450.4 & 6.94 & 43.56 \\
\hline 20 & 3.41 & 266.3 & 399.8 & 26.31 & 429.8 & 24.81 & 50.98 & 3.36 & 270.2 & 405.7 & 24.34 & 467.7 & 17.1 & 45.69 \\
\hline 68 & 2.98 & 266.4 & 401.1 & 29.22 & 427.6 & 29.87 & 51.87 & 2.88 & 270.5 & 409.3 & 27.12 & 447.1 & 11.2 & 45.85 \\
\hline 92 & 3.39 & 270.4 & 347.2 & 15.65 & 398.3 & 19.51 & 53.12 & 3.21 & 276.4 & 341.0 & 13.21 & 404.9 & 19.2 & 45.93 \\
\hline 150 & 3.66 & 271.3 & 341.1 & 15.02 & 390.2 & 18.35 & 53.79 & 3.42 & 278.5 & 337.2 & 12.93 & 398.5 & 20,12 & 46.88 \\
\hline 200 & 3.87 & 272.2 & 332.4 & 14.96 & 384.8 & 17.76 & 55.94 & 3.69 & 282.5 & 335.1 & 12.02 & 391.3 & 23.16 & 48.02 \\
\hline
\end{tabular}

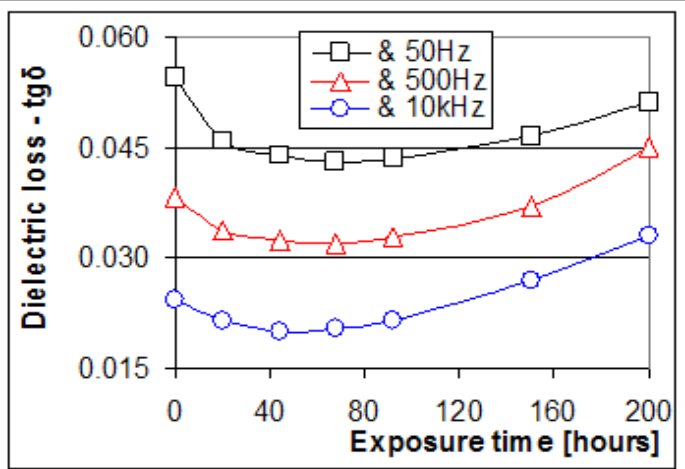

Fig. 7. Evolution of dielectric losses to PSM3 depending on the duration of exposure to UV $60 / \mathrm{m}^{2}$

By comparing figure 7 and figure 8 with the data from table 3 it is found that, for epoxy materials (PSM1 and PSM2), the minimum values of $\operatorname{tg} \boldsymbol{\delta}$ correspond to the maximum values of $T_{\text {max } 1}$, respectively the maximum thermal stability of the maxterial. This finding indicates that the ageing of the investigated painting materials reflects a direct correlation between the evolution of the maximum temperature characteristic of the first thermooxidation process and the evolution of the dielectric (dielectric losses - $\operatorname{tg} \boldsymbol{\delta})$ performances.

\section{Conclusions}

Combined techniques of thermal analysis and dielectric spectroscopy can be successfully used to study ageing by exposure to UV radiation of epoxy and polyurethane resin coating materials. Following the processing of experimental data obtained on epoxy resin based materials, it was found that exposure to irradiation with UV $60 \mathrm{~W} / \mathrm{m}^{2}$ increases the mass losses $\Delta \boldsymbol{m}_{\mathrm{v}}$ due to the formation of volatile products as a result of structural ordering process (polymerization /crosslinking) which significantly increases the crystallinity of the material, showing an endothermic $\boldsymbol{T}_{M}$ peak of the melting process and also decreases the dielectric losses to $\delta$ in the material.

At various times/ doses higher than approx. $19.5 \mathrm{MJ} / \mathrm{m}^{2}$ (about $90 \mathrm{~h}$ of irradiation at $60 \mathrm{~W} / \mathrm{m}^{2}$ ) a marked degradation process is triggered characterized by an excessive increase in $\boldsymbol{T}_{\boldsymbol{M}}$ and a significant decrease in the characteristic temperatures at which take place the first thermooxidation process occur with the formation of solid peroxide products, $\mathbf{0 1}$ as well as $\mathbf{0 2}$ and $\mathbf{0 3}$ thermal oxidation processes with the formation of volatile products, and also the increase of the total mass losses Ä $m_{T}$ to 600 ${ }^{\circ} \mathrm{C}$, which process substantially increases the recorded $\mathbf{t g} \boldsymbol{\delta}$ values.

Unlike epoxy materials, for investigated UV unexposed polyurethane materials, progressive heating up to the endothermic melting process $\boldsymbol{M}$ did not show loss of mass through the formation of volatile products. After exposure to UV $\left(60 \mathrm{~W} / \mathrm{m}^{2}\right)$ before melting the material to $T_{M}$ a first $\boldsymbol{V}$ process of decomposition occurs through the formation of

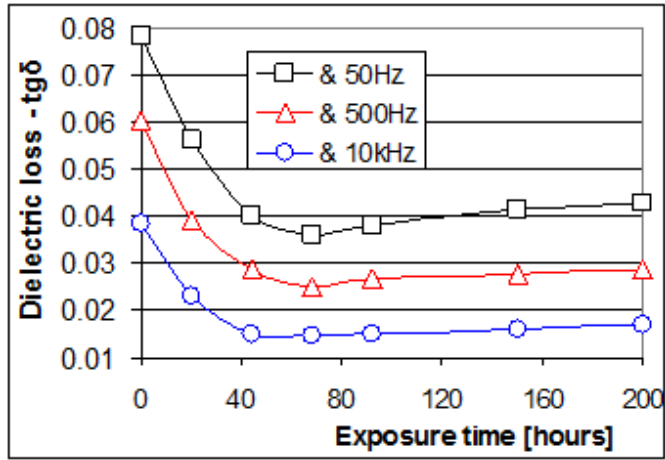

Fig. 8. The evolution of dielectric losses at PSM4 depending on the duration of exposure to UV $60 \mathrm{~W} / \mathrm{m}^{2}$

volatile products. Both $\Delta \boldsymbol{m}_{v}$ and $\boldsymbol{T}_{M}$ continuously increase at exposure times increasing.

In the first approx. $70 \mathrm{~h}$ of UV irradiation (up to an irradiation dose of about $15.1 \mathrm{MJ} / \mathrm{m}^{2}$ ), dielectric losses are decreasing and temperatures typical of the $T_{\text {Max } 1}$ and $\boldsymbol{T}_{\text {MaxO2 }}$ thermooxidation processes are increasing, indicating a stabilization of the material.

When increasing the radiation dose to over $15.1 \mathrm{MJ} / \mathrm{m}^{2}$, a degradation process is triggered, characterized by a significant decrease in the characteristic temperatures at which both the first $\mathbf{0 1}$ thermooxidation process occur (with the formation of solid peroxide products) and the thermooxidation processes $\mathbf{0 2}$ and $\mathbf{0 3}$ (with the formation of volatile products), as well as the increase in total mass losses $\Delta m_{T}$ at $600^{\circ} \mathrm{C}$, process which substantially increases the recorded tg $\delta$ values.

These findings and observations indicate that the ageing of the investigated coating/painting materials has a direct correlation between the evolution of the thermal parameters $\left(\Delta \boldsymbol{m}_{\tau}\right.$ at $600^{\circ} \mathrm{C}$, the maximum temperature characteristic of the thermooxidation processes $T_{\text {Maxo1' }}$ $T_{\text {Max02 }}$ and $T_{\text {Maxo3 }}$ ) and the dielectric losses evolution - $\operatorname{tg} \delta$.

Acknowledgment: This work was financially supported by the UEFISCDI of Romania, under the scientific Programme NUCLEU 2016 - 2017" contractPN 161102 11/2016.

\section{References}

1. OPRINA, G., RUS, T., LINGVAY, D., CARAMITU, A., MITREA, S., Electrotehnica, Electronica, Automatica -EEA, vol. 65 (1), 2017. pp. 81-87

2. YANG XF, VANG C, TALLMAN DE, BIERWAGEN GP, CROLL SG, ROHLIK S., Polymer Degradation and Stability 74, (2), 2001, pp. 341351.

3. CARAMITU, A., BUTOI, N., RUS, T., LUCHIAN, A.M., MITREA, S., Mat. Plast., 54, no. 2, 2017. p. 331

4. HU, J., LI, X., GAO, J., ZHAO, Q., Progress in Organic Coatings, 65, 2009, pp. 504-509.

5. HU, J., LI, X., GAO, J., ZHAO Q., Materials \& Design, vol. 30, 2009, pp. 1542-1547. 
6. AWAJA F., PIGRAM J .P., Polymer Degradation and Stability, vol. 94, 2009, pp. 651-658.

7. HU, J., LI X., GAO, J., ZHAO, Q., Materials \& Design vol.30, 2009, pp. 1542-1547.

8. FOIX D., RAMIS X., SERRA A., SANGERMANO M., Polymer 52, 2011, pp. 3269-3276.

9. HUANG, W., ZHANG, Y., YU, Y., YUAN, Y., Inc. J Appl Polym Sci, vol. 104, (6), 2007, pp. 3954-3959.

10. CARAMITU, A., VOINA, A., RUS, T., LINGVAY, I., Proceedings of DEMISEE 7530466, 2016. pp. 60-65

11. ZHOU, G., Li, L., WANG, S., JIAO, H., Li, S., 15th International Conference on Experimental Mechanics, Porto/Portugal, 22-27 July 2012, PAPER REF: 2954

12. YANG, X.F., TALLMAN, D.E., BIERWAGEN, G.P., CROLL, S.G., ROHLIK, S., Polymer Degradation and Stability, vol.77, 2002, pp. 103109.

13. DIMOFTE, M., BUNEA, M., CAPATINA, A., COJAN, A., BOSOANCA, R., CIRCIUMARU, A., Mat. Plast., 54,, no. 2, 2017, p. 362

14. CHANDRASEKARAN, S., SEIDEL, C., SCHULTE, K., Eur. Polym. J., vol. 49, (12), 2013, pp. 3878-3888.

15. CIOBOTARIU, O.R., BRIA, V., GRAUR, I., VOINESCU, D.C., Rev. Chim. (Bucharest), 66, no. 11, 2015, p. 1903.

16. LINGVAY J., BUDRUGEAC P., Korrozios figyelo, vol.48, (3), 2008, pp. 45-50.

17. LINGVAY J ., SZATMARI I., LINGVAY M., TUDOSIE L., Korrozios figyelo, vol. LIII (3) 2013, pp. 71-80.

18. SZATMARI, I., LINGVAY, M., VLADOI, C., LINGVAY, I., Electrotehnica, Electronica, Automatica-EEA, vol. 61, no. 4, 2013, pp. 48

19. BORS, A.M., BUTOI, N., CARAMITU, A.R., MARINESCU, V., LINGVAY, I., The Thermooxidation and Resistance to Moulds Action of Some Polyethylene Sorts Used at Anticorrosive Insulation of the Underground Pipelines, Mat. Plast., 54, no. 3, 2017, p. 447

20. SIVAN A., Current Opinion in Biotechnology, vol. 22, 2011, pp. 422426.

21. UMARE S. S., CHANDURE A. S., Chemical Engineering J ournal, vol. 142, 2008, pp. 65-77.

22. LEJA K., LEWANDOWICZ G., Polish J. of Environ. Stud., vol. 19, (2), 2010, pp. 255-266.

23. RADU, E., LIPCINSKI, D., TANASE, N., LINGVAY, I., Electrotehnica, Electronica, Automatizari- EEA, vol. 63, (3), 2015, pp. 68-74.

24. STANCU, C., LINGVAY, M., SZATMARI, I., LINGVAY, I., The 8th International Symposium on Advanced Topics in Electrical Engineering, Bucharest, Romania, May 23-25, 2013., IEEE Catalog Number CFP1314P-CDR.

25. LINGVAY, M., STANCU, C., SZATMARI, I., LINGVAY, I., Electrotehnica, Electronica, Automatica-EEA, vol. 61, (1), 2013, pp. $43-47$.

26. LOREDO-TREVINO, A., GUTIERREZ-SANCHEZ, G., RODRIGUEZHERRERA, R., AGUILAR, C.N., J Polym Environ, vol. 20, 2012, pp. 258265.

27. LINGVAY, I., VOINA, A., LINGVAY, C., MATEESCU, C., Revue Roumaine des Sciences Techniques serie Electrotechnique et Énergetique, 53, (2bis), 2008, Avril-J uin, pp. 95-112.

28. ZAKOWSKI, K., DAROWICKI, K., Polish J. of Environ. Stud., vol. 8, (4), 1999, pp. 209-212.

29. LINGVAY, I., LINGVAY, C., VOINA, A., Revue Roumaine des Sciences Techniques serie Electrotechnique et Energetique, 53, (2bis), 2008, Avril-Juin, pp.85-94.

30. VOINA, A., MARIN, D., NITA, P., LUCHIAN, A.M., LINGVAY, D., BUTOI, N., LINGVAY, I., Electrotehnica, Electronica, Automatica- EEA, vol. 65, (2), 2017, pp. 60-65.

31. LINGVAY, I., RUS, G., STOIAN, F., LINGVAY, C., UPB Sci. Bull, Series B, vol. 63, (3), 2001, pp. 263-270.

32. LINGVAY J ., Korrozios Figyelo, vol. 44, (1), 2004, pp. 49-56.
33. PRIOTEASA, P., LINGVAY, M., SZATMARI, I., BURUNTEA, N., LINGVAY, I., Electrotehnica, Electronica, Automatica-EEA, vol. 62 (2), 2014. pp. 60-65.

34. LINGVAY, J., SZATMARI, I., PRIOTEASA, P., LINGVAY, M., TUDOSIE, L. M., Korrozios Figyelo, vol. 54, (1), 2014, pp. 15-21.

35. LINGVAY J., RADU E., MITREA S., LINGVAY M., UDREA O., SZATMARI I., Korrozios Figyelo, vol. 54, (2) 2014, pp. 40-46.

36. LINGVAY, I., RUS, G., BURUNTEA, N., UPB Sci. Bull, Series B, vol. 63, (3), 2001, pp. 29-36.

37. RADU, E., MITREA, S., UDREA, O., PATROI, D., MARIN, D., Electrotehnica, Electronica, Automatica - EEA, vol. 63, (2), 2015, pp. 110-115.

38. SZATMARI, I., TUDOSIE, L.M., COJOCARU, A., LINGVAY M., PRIOTEASA, P., VISAN, T., UPB Sci. Bull, Series B, vol. 77, (3), 2015, pp. 91-102.

39. COJ OCARU, A., PRIOTEASA, P., SZATMARI, I., RADU, E., UDREA, 0., VISAN, T., Rev. Chim. (Bucharest), 67, no. 7, 2016, p. 1264

40. DIMOFTE, M., BUNEA, M., CAPATINA, A., COJAN, A., BOSOANCA, R., CIRCIUMARU, A., T, Mat. Plast. 54, no. 2, 2017, p. 362

41. CRACIUN, E., IONCEA, A., JITARU, I., COVALIU, C., ZAHARESCU, T., Rev. Chim. (Bucharest), 62, no. 1, 2011, p. 21

42. GHASEMI-KAHRIZSANGI, A., NESHATIA, J., SHARIATPANAHI, $H_{\text {., }}$ AKBARINEZHAD, E., Prog. Org. Coat., vol. 85, 2015, pp. 199-207.

43. GHASEMI-KAHRIZSANGI, A., SHARIATPANAHI, H., NESHATIA, J., AKBARINEZHAD, E., Appl. Surf. Sci., 353, 2015, pp. 530-539.

44. PICA, A. FICAl, A., Rev. Chim. (Bucharest), 67, no. 1, 2016, p. 34 45. PANAITE, V., BOICIUC, S., MUSAT, V., Rev. Chim. (Bucharest), 66, no.2, 2015, pp. 231-218.

46. ALMEIDA, E., DIAMANTINO, T. C., ORLANDO DE SOUSA, Progress in Organic Coatings, vol. 59, (1), 2007, pp. 2-20.

47. STATZ, A.R., MEAGHER, R.J., BARRON, A.E., MESSERSMITH, P.B., J. Am. Chem. Soc., 127 (22), 2005, pp. 7972-7973.

48. HOWARD, G.T., Polymer Recycling, Editors: A. Fainleib and 0.Grigoryeva, 2011. pp. 215-238

49. PICA, A., FICAI, A., FICAI, D., GURAN, C., DUMITRU, F., U.P.B. Sci. Bull., Series B, vol. 77, (3), 2015, pp. 115-130.

50. BRIA, V., CIRCIUMARU, A., BIRSAN, I.G., Mat. Plast., 48, no. 2, 2011, p. 189.

51. LINGVAY, I., STANCU, C., BUDRUGEAC, P., CUCOS, A., LINGVAY, C., ATEE 2011, The $7^{\text {th }}$ International Symposium on Advanced Topics in Electrical Engineering, May 12-14, 2011, Bucharest, Romania, pp. 437-440.

52. BUDRUGEAC, P., J ournal of Materials Science, vol. 36, (12), 2001,pp. 2999-3001.

53. GRAUR, I., BOSOANCA, I., BOSOANCA, R., BODOR, M., CIRCIUMARU, A., Rev. Chim. (Bucharest), 66, no.11, 2015, p. 1759.

54. BUDRUGEAC, P., Thermochimica Acta, vol. 500, (1-2), 2010. pp. 3037.

55. BUDRUGEAC, P., SEGAL, E., J ournal of Thermal Analysis and Calorimetry, (JTAC), vol. 53, (3), 1998, pp. 801-808.

56. VLAD, S., Mat. Plast., 45, no. 4, 2008, p. 394

57. ISOC, D., IGNAT - COMAN, A., JOLDIS, A., AIP Conference Proceedings 1019, 383, 2008.

58. ISOC, G., ISOC, T., ISOC, D., Studies in Computational Intelligence (SCI), vol. 486, 2013, pp. 53-64.

59.*** Sigmacover 456: http://www.ppgpmc.com/Products/7466/ SIGMACOVER-456.aspx

60.***Intergard 410: http://www.international-marine.com/products/ info/intergard-410.aspx

61.***Hardtop:http://w w w.jotun.com/Datasheets/Dow nload?url $=\% 2 F T D S \% 2 F T D S$ _49_Hardtop+AS_Euk_GB.pdf

62. ***Sigmadur 550H: http://www.ppgpmc.com/Products/7537/ SIGMADUR-550.aspx

Manuscript received: 10.08 .2017 